\title{
Historicity, responsibility, subjectivity
}

\section{Couze Venn ${ }^{1}$}

Published online: 10 March 2020

○) Springer Nature Limited 2020

As we look back at the theoretical and political transformations that have shaken modern times, it becomes clear that two forms of interrogations have profoundly disrupted the convictions and visions upon which we had relied for a long time to make sense of ourselves and of the world. The first set of questioning has its roots in the aporias of the narratives that have authorized a particular conceptualization of being and of agency in the discourses of modernity; it has excavated the faultlines beneath the foundations that underpinned the view that the narrative of being could be figured in terms of one history, one humanity, one subjectivity. The second challenge comes from those denied agency and authority, inscribed as they are in the margins of the triumphalist history of the subject, those who have sought to dismantle the foundations from a standpoint located in the in-between or border or undecidable terrain of subordination and marginalization. The interpenetration between the two lines of interrogation, for instance the degree to which something called 'postcolonial' theory borrows from or assumes a corpus of claims and statements established within something called poststructuralism, is not so much the sign of complicities and forgettings at the moment of the 'post' as it is an indication of how the world has been altered by modernity in ways that we are only beginning to understand or come to terms with.

The question that at first I want to tease out of these disjunctions can be posed in the form that Foucault gave to it: 'Who are we in the present?' It is a formula that combines the ageless anxiety of being confronting its constant dissolution and its finitude with the recognition of the historicity of that interrogation. In a sense it is also an eminently modern formulation of the problem of history and of subjectivity enclosing two themes central to the questioning of the foundations of the discourses of modernity. It recalls Ricoeur's and Heidegger's understanding of being as the entity that questions itself as to its way of being and, like

Originally published as "Chapter 2: Historicity, responsibility, subjectivity" (pp. 72-106) in Venn, Couze (2000) Occidentalism: Modernity and Subjectivity. London: Sage.

Couze Venn-Deceased.

\section{Couze Venn}

1 London, UK 
them, emphasizes the dimension of temporality, since the presence of the present at the heart of Foucault's formulation signals how much this questioning is bound up with the consciousness of ourselves as beings in time (Lloyd 1993). It recalls too the experiential or ontic dimension of temporality and self-reflexivity, foregrounded at the beginning of Marshall Berman's analysis of modernity where he says that:

To be modern is to find ourselves in an environment that promises us adventure, power, joy, growth, transformation of ourselves and the world \pm and, at the same time, that threatens to destroy everything we have, everything we know, everything we are. ...[Modernity] is a paradoxical unity, a unity of disunity: it pours us all into a maelstrom of perpetual disintegration and renewal, of struggle and contradiction, of ambiguity and anguish. (1983, p. 15)

I evoke this particular passage because it captures so well the underlying themes that the experience of modernity has provoked in the different forms \pm philosophical discourse, fictional narrative, artistic works \pm in which that experience of living at the limits, of pushing at the limits, has been expressed. So many of those who have addressed the experience of modernity convey the restlessness of spirit, the pervading anxiety that troubles even the steadiest of minds, like Kant when speaking about the sublime and about judgement. Indeed, behind or beneath the panache of logocentric certainties, which a certain critique deems the overwhelming characteristic of the discourses of modernity, we find the disquiet of the Rousseau of the Confessions, the anxieties of Hegel at Jena, the hesitations of Schelling, or of Freud in his correspondences, we pick up on the pathos in the works of a Dostoevsky or Sartre or in Beethoven's Eroica; closer to home, we share the torment of a Samuel Beckett and the ironies of Salman Rushdie. Modernity, from the beginning, has been a fractured dream, yet driven by an immense energy and an arrogant confidence that has transformed the world to an extent that no other period has ever accomplished. Nothing of the social and the physical habitat has been left untouched. It follows that a condition for overcoming the limits of modernity is that we must refigure this event as we wonder again who we are in the present.

It is possible that modernity simply provided conditions that amplified an existential anguish that all cultures have shared for a considerable time, an anguish that gripped the spirit as soon as human beings became conscious of themselves as finite beings who could measure their constant fading and envisage their inevitable ending against the longtime of history. The coming-to-consciousness is at once a coming to self-consciousness and the emergence of conscience, the discovery that one comes naked into the world, abandoned to a fragile freedom and to responsibility for one's actions and one's destiny. One of the most powerful myths of origin, the Judeo-Christian story of Adam and Eve could be read as a parable on the dilemmas of freedom and of the knowledge of finitude, the realization that to know is to be responsible, and that freedom is a responsibility. Knowledge and responsibility have come to refer to each other, in the discourse of 
religion as much as in that of the Enlightenment narrative of the progress of Reason and the possibility of emancipation. What being comes to know is the openness of the future, that is to say, the historicity of being, so that responsibility is responsibility for the present and for what might come in the future. Equally, the genealogy of the 'subject' brings out the extent to which from the beginning profound correlations emerged between the experience of the abyss and the anticipation of jouissance, between finitude and the exhilaration of risk, between lack and loss and desire.

Let me pursue this line of thought by engaging with the connection between responsibility and historicity and the transmutation of historicity into the promise of emancipation. The idea I want to examine is that the grand narratives of modernity are but the refigured and secular form of a more archaic search for a principle of hope born out of the foreknowledge of the possibility of pleasures renewed, and, on the dark side, the anguish of contingency and death. The promise of joy, figured as a narrative of redemption or a narrative of emancipation or the imagined fulfilment of desire, is premised on this recognition of finitude and the wound of loss and lack. Additionally, as I will demonstrate in the next chapter, the specificity of the modern narrative of being and of the history of modernity and of how its subject is bound up with the history of modern colonialism and of capitalism.

I would like at first to examine what Derrida (1995) has called 'the gift of death', to ask what is given with death, that is, the sense in which this original violence is also a gift, that is, it enters the relation between the economy of the gift and the economy of sacrifice whereby the trembling of being is tethered to the secret of some ulterior and unfathomable destiny. In his reflections on the thought of Jan Patocka which generates the text of The Gift of Death, Derrida reminds us that the stakes in Patocka are defined as 'the birth of Europe in the modern sense of the term' (1995, p. 3), and an exploration of what 'ails "modern civilization" in as much as it is European' (1995, p. 3). Already, the question of Europe and of modernity is tied up with the more general question of historicity. I note this context because my own analysis includes the understanding of the becoming-West of Europe and the becoming-modern of the world as conjoined processes, that is, the understanding of the conceptual space of occidentalism.

Now, if we add the connection between responsibility and historicity to the equation about occidentalism, a number of themes begin to emerge, adding to those I have introduced earlier, that are central to the deconstruction of the discourses of modernity and vital for the reconfiguration of the future after or beyond modernity. Derrida's development of the relationship between historicity and responsibility is to argue that religion is the first form of 'a passage to responsibility' (1995, p. 2) and the birth of an ethical conscience. But the Christian tradition finds it difficult to acknowledge this relation, preferring to imagine that the origin of responsibility proceeds from an unconditioned desire, interior to the soul of human beings, to seek the good. Recognition of the historicity of responsibility would break the link to faith, and to the gift, thus to a secret or mystery, namely, 'the mysterium tremendum: the terrifying mystery, the dread, fear, and trembling of the Christian in the experience of the sacrificial gift' $(1995$, p. 6). This gift is that of death, at first given with the banishment or fallenness of Adam and Eve, then demanded of Abraham 
in the sacrifice of his son Isaac, himself a gift to Abraham from God, and finally, I should add, the gift of the death of Jesus to humankind, the redeeming sacrifice, which also works as the pledge that secures faith and trust in God. The interesting difference in the Christian scene is that the gift of death is transmuted into the promise of immortality, that is to say, the cancelling of finitude for all Christians. Equally, I would point to the transmutation of the trembling of being into the experience of an immortal interiority, attuned to the discipline of a care or solicitude for death: 'a vigil over the possibility of death', as Derrida puts it (1995, p. 12), the anticipation of its proximity turned into a relation to the self, a care of the self, the theme that Foucault famously developed. The birth of a discourse of an individualized, interiorized soul and subjectivity can be inferred from this line of analysis, describing a 'subjectivizing interiorization, the movement of the soul's gathering of itself, a fleeing of the body toward its interior where it withdraws into itself in order to recall itself to itself, in order to be next to itself, in order to keep itself in this gesture of remembering' (1995, p. 13, original emphasis). Derrida here rewrites the passage in Plato's Phaedo relating to the assembling of the soul into itself, which also can be read as the recognition of the self's relation to death and finitude, as does Levinas in his commentary on the same passage. An underlying theme in the Heideggerian problematic of being surfaces here, figured in terms of an 'egological subjectivity', linking in its make-up 'care, being-towards-death, freedom and responsibility' (1995, p. 19). Indeed, the surprising element in the way I am recasting a genealogy of subjectivity is the extent to which even the Heideggerian attempt to break with a particular metaphysics and a particular ontology can be seen to remain attached to a more archaic, traditional thematic of being with its root in religion and in Plato, that is, in the crossing of the Judeo-Christian narrative of being and Greek thought. I shall have occasion to return to this fateful/fatal crossing in my examination of the birth of modernity and the modern subject. I should note at this point a thought of Levin, which keeps visible the position that sets the pessimism anchored in the soil of Thanatos or being-towards-death against the ecstasy of Being withheld within the 'unrealized power of Eros. For Eros is, in truth, an immortal aspect of Physis: its sheer energy and ecstasy of Being' (1985, p. 2). The body's remembrance of Being is the key for a new task: 'the humanization of our sensibility and the culture of our capacities for perception' (1985, p. 31, original emphasis). ${ }^{1}$

One might well wonder then what displacements and what disavowals inaugurate the modern discourse of subjectivity. And what has been the history, or cryptology, as Derrida would put it, of the secrets buried with the forgettings, particularly of the relation to the other and the difference of the other, forgettings which produce the singularity and interiority of the egocentric subject? History, however, "never effaces what it buries; it always keeps within itself the secret of what it encrypts' (Derrida 1995, p. 21); traces are left that genealogy can uncover. But where does one look, and what are the questions to ask of the texts that authorize occidentalism?

\footnotetext{
1 The elaboration of this task takes Levin through a reading of Heidegger and Merleau- Ponty juxtaposed with an interpretation of Freud and Jung, a road I have not pursued here.
}

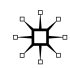




\section{Emancipation}

In a surprising coincidence \pm but why should it surprise us? \pm Lyotard, reflecting on precisely the same events and paradoxes that Derrida explores in The Gift of Death, comes to this conclusion:

With the modern thinkers, since Paul and Augustine, the promise of emancipation was what ordered time along a history or, at least, according to a historicity. For promise required setting out on a journey of education, the emergence from a condition of prior alienation, in the direction of a horizon of a legitimate jouissance [jouissance du propre] or of a liberation. Duration acquires the sense of an orientation filled with waiting and labour. (1993, p. 11)

The idea of the human condition as something motivated by the expectation of an emancipation is not specific to the Semitic religions alone. The same underlying idea reappears in all the major cultures the world over, for instance in the notion of a journey towards Nirvana through a series of reincarnations, or in the idea of the getting of wisdom by reflection and through suffering and learning, a wisdom that necessarily liberates us from whatever mortifies us. The model of a journey from infancy towards adulthood is precisely the model that we encounter in Kant's (1992 [1784]) definition of the Enlightenment as the passage of humanity from its state of immaturity towards its maturity and autonomy, charting a process of liberation from dependency and ignorance.

All these narratives speak of a difficult journey of discovery in the course of which the individual must renounce the wants and interests that shackle us to suffering and lack. Christian thinking defers the denouement, to the next life, routinizing sacrifice into the daily effort of the pilgrim to deserve the reward of an eventual emancipation. ${ }^{2}$ For Lyotard, sacrifice and deferral create an ethical tension into which modern philosophy 'grafted... the eschatology of a knowledge [savoir] which is at the same time a will for the emancipation of meaning, always in process' (1993, p. 11). He points out that contemporary thinking shortens the delay, thus abolishing the historicity of emancipation. It also thereby abolishes the sense of an initial or original lack or loss which drives the desire for emancipation. The discourse of modernity emerges out of the break with the Judeo-Christian idea that emancipation could only be pursued through a listening to the proper, authentic authority, recorded in the sacred texts that one must learn to interpret. The good interpretation came out of a process of learning how to listen and how to read; it is an hermeneutics that prepares us for the coming to wisdom or to grace. Modernity sought to achieve its emancipation by itself, requiring no other help or means save its own effort and its own decision, gradually extending its power over whatever stood as obstacles to the exercise of a dominion that conditioned autonomy, and the exercise of a liberty that itself appeared as the proof of emancipation. Today, something inadequately called the postmodern has emerged which completes the disappearance of historicity,

\footnotetext{
${ }^{2}$ Bunyan's Pilgrim's Progress is an early example of the resilience of the theme of Homo viator in the modern era.
} 
this completion itself standing for the sign of postmodernity. Of this flight into an absent-minded future, Lyotard says: 'it is as if a paganism without Olympus and without the Pantheon, devoid of prudentia, without fear, without grace, recognizing no debt, and desperate, was being reconstituted' (1993, p. 15, original emphasis).

One can understand this orientation in the modern project by refiguring the meaning of the hyphen which separates yet joins Judaism and Christianity and, I would add, the silent hyphen which attaches the Judeo-Christian discourse to that of modernity. Like Derrida, Lyotard finds a point of departure in the episode of the sacrifice of Isaac by Abraham, the trial or temptation of Abraham, to test his faith and his submission. Lyotard derives from this story the sense of a dread at the heart of the anticipation of salvation, even in extremis, which the faithful expects from God: what if God does not provide (the ram, in the case of the Holocaust of Isaac)? A dimension of secrecy is inscribed in this not knowing: God's will is the lettre de cachet that only the future reads; we only know afterwards, and must ever act without knowing. Perhaps a distinguishing feature of fundamentalism \pm whether based in religion or in a science \pm is the claim to know in advance, the claim to certainty, whereas there must always remain an element of doubt. Sacrificial faith demands that faith be absolute: for instance, in the civilizing mission of imperialism which envisaged the sacrifice of whole cultures to the promise of an occidentalist future; in Stalinism and its justification of the wholesale liquidation of categories of people, as in the Soviet Union or in Cambodia; or in monetarism and its sacrificial policies today (when it is not merely political cynicism).

Let us return to the text of Derrida, who directs us to another lesson about responsibility. For one thing, he tells us, Abraham is free to refuse, and he must face the paradox of duty and absolute responsibility, having to decide in secrecy, that is, by himself, without guidance, which is the highest duty or responsibility: the duty owed to his son, or that owed to God and responsibility towards the community. Secrecy and transcendence are 'essential to the exercise of this absolute responsibility as sacrificial responsibility' (1995, p. 67). For Abraham, to speak about the command, to share with others the responsibility by allowing them to guide his decision, would betray a lack of faith, in wondering if God's commandment should be carried out. The relation to the absolutely transcendent Other must be absolute, and must remain secret, that is, uncommunicated and unknown.

There is another paradox concerning the problem of responsibility. Prompted by the work of Levinas, which aligns the question of responsibility to the problem of thinking the relation to the other, Derrida says:

As soon as I enter into a relation with the other, with the gaze, look, request, love, command, or call of the other, I know that I can only respond by sacrificing ethics, that is, by sacrificing whatever obliges me to also respond, in the same way, in the same instant, to all the others. I offer a gift of death. I betray. (1995, p. 68).

I think there are two aspects concealed in this impasse; on the one hand there is the implication that the call to a responsibility for the other cannot be answered because as soon as I respond to a particular named person, I abandon all others, which is the implication that Derrida is pursuing. I think Derrida's pessimistic reading does not 
sufficiently distinguish between the principle of an abstract responsibility and the phenomenal or ontic reality of its enactment, when it is our conduct with regard to specific others that gives content to the principle; it is the only way it can be cashed out. On the other hand, it could be argued that I am called to this responsibility precisely because it is in the name of all others that I am held to be responsible. The principle of responsibility, and what underlies it, is prior to any act on my part, though it derives from a history of responsibility, that is to say, from the memory of an immemorial debt owed to all, but to victims in particular. There remains, nevertheless, a dilemma which only an idea of justice and the exercise of conscience can mediate in practice, so that in expressing responsibility for a particular other I am obliged to make an ethical judgement. It is in the absence of justice and conscience that I betray and kill. For example, I may forgive an oppressor for my own suffering, but I have no right to do so on behalf of another's suffering. Dostoevsky's instructive story 'Why does God permit evil?', from The Brothers Karamazov, illustrates the dilemmas involved in deciding what one may forgive and what it means to forgive, and on behalf of whom may we forgive. It incidentally shows the impossibility of overcoming some 'differends' when justice involves those who are no longer alive, unless one were to invoke some redemptive sacrifice like that of Christ. I have indicated, in Chapter 1, that the exercise of a conscience is the result of an apprenticeship and thus tied to historicity, that is to say, tied to the accumulated wisdom dispersed in the memory and 'texts' of a culture, and which one must learn through an hermeneutical praxis. If we were to consider historicity and conscience to be separated and conjoined by the spacing of differance, we could then think that it is precisely the caesura produced by the forgetting of that relation in the concept of transcendent origin(s), or in originary moments \pm for example, in the idea of original $\sin \pm$ that allows the idea of an absolute other to be insinuated. ${ }^{3}$ The search for ontological security in the guarantee of transcendentals is paid for in terms of the sacrifice of the other, specifically the other who can be excluded on the basis of otherness or unbelonging, that is, those who are not recognized by the Other, or those who cannot be gathered into the sameness of an originary identity, for instance in the notion of race, the ethne or the faithful. Furthermore, within the narratives of being in the Abrahamite religions, the consciousness of temporality is tied to a sense of abandonment and lack or fallenness, provoking the repression of the trace of the becoming-conscious, and its incorporation or inscryption in the interiority of the soul.

The line which Derrida explores instead implies that the absolutely other \pm Other or God, and thus a transcendent principle demanding the sacrifice of a life, an infinite gift \pm is an idea that feeds sacrificial war, so that the place where death is given in the story of the sacrifice of Isaac is today a place of dissent and discord, 'fought over by all the monotheisms, by all the religions of the unique and transcendent God, of the absolute other' (1995, p. 70). Derrida reminds us that this place is located on Mount Moriah at the place called the Dome of the Rock, in Jerusalem, near the Aska Mosque associated with the sacrifice of Ibrahim; it is where

\footnotetext{
${ }^{3}$ Is the gap also the space which metaphysics is made to fill?
} 
Solomon decided to build the House of the Lord, and where once stood the grand Mosque of Jerusalem; today, it stands above the Wailing Wall and close to the Way of the Cross. It is worth pointing out that in the discourse of Western philosophy, the hyphen linking Judaism and Christianity silently erases Islam from Semitic thought, casting the Islamic world into invisibility when it comes to a genealogy of modernity. Derrida, to his credit, has constantly addressed the Eurocentric assumptions of the discourse of modernity, for instance, regarding the implication in Kant that the European hegemony was somehow a hidden design in nature, a 'teleological ruse of nature' that would have prescribed the privilege of Greco-Roman Europe in the foundation of history as the history of the emancipation of the whole of humanity (Derrida 1997, pp. 26-30). I shall have more to say about the question of monotheism and transcendence in Chapter 3, in my analysis of the repetitions of the same and the unique, that is, the plays of identity in the secularization of the narrative of emancipation, the stratagem which inaugurates modernity as a project that preserves and retains the desire for Oneness and the Same in the priority it grants to the idea of one history, one humanity, one subjectivity.

Another aspect to examine concerns the trembling of being when exposed to the complete unknowability of the future and to a power beyond comprehension. A vital difference appears here between Judaism and Christianity. In the eschatology of Judaism, the promise of emancipation, not guaranteed by an event like the sacrifice of Jesus, does not tell the Jew how to act in the present. The commandments do that, but there is an abundance of them, and they are open to interpretation. Conscience acquires a different meaning, therefore, as both obedience to the law (Halakah), that is, the discharge of a performative duty, and a decision regarding the good for which reflective judgement must rely on the enigma of wisdom. By contrast, in the case of Christianity, the promise of emancipation or redemption has clear implications about how one is to act in the world. In both cases, though, there is the injunction to constantly inspect one's conscience; indeed, to imagine that one has a conscience, whence also arises a paradox of responsibility that Derrida (1995) points out, namely, that the logic of the assumption that one knows what one does opens up the possibility that a science, or an objective set of rules for decision-making on the basis of a science or of a knowledge, could absolve conscience of responsibility for decision or judgement. The history of modernity provides ample evidence of this temptation, within a secular narrative of becoming, to shift the burden of responsibility onto a positive science rather than face up to the fact that the subject of responsibility is a named person and that the responsible person is 'this exposing of the soul to the gaze of another person, of a person as transcendent other, as an other who looks at me, but who looks without the-subject-who-says-I being able to reach that other, see her, hold her within the reach of my gaze' (Derrida 1995, p. 25). The Levinasian conceptualization of the face relation and the absolute alterity of the other for whom I am nevertheless responsible is evident in this formulation. ${ }^{4}$ So, on

\footnotetext{
${ }^{4}$ I should emphasize that alterity is not otherness. Alterity does not implicate alienness but separation from myself, as an other, but an other who remains inaccessible. Not only must I respect the singularity of the other, I cannot take the place of the other. The test of alterity, it could be argued, is that I cannot take upon myself the suffering of the other \pm my child, a lover \pm in order that she may not suffer, however much I may wish to.
} 
the one hand, we find the instrumentalization of responsibility and of judgement into a fixed set of rules to be followed, that is, we find the privileging of logos and, at its extreme, a performative rationality, whilst, on the other hand, there remains the burden of knowing that one only half-knows, that there are no guarantees, yet that one must act as if for the first time, re-enacting the diremptions inherent in the ethical.

Lyotard (1993) comes to this point in a rather different way that throws added light on the question of the specificity of modernity and its form of subjectivity. He argues that neither in the secular discourse of the West nor in the Christian discourse is there a clear answer to the question of what it means to be liberated, which is the goal of emancipation, that is, the liberation from temporal powers that constrain our liberty or inflict pain upon us, or the overcoming of an interior insufficiency, a weakness of the soul, whatever keeps us in the state of infancy or immaturity \pm to signal again Kant's definition of the Enlightenment. Lyotard points out that it comes down to maintaining the separation between the three orders which distinguish the different stakes of judgement, that is to say, truth, the good and the beautiful. However,

the Western modern ideal of emancipation combines all the orders; to ensure for oneself complete possession [ownership] over knowledge, over the will and over feeling. To give to oneself the rule of knowledge, the law of the will [vouloir], and the control over affect. He will be emancipated who owes nothing to anyone but himself. Liberated from any debt owed to the other. (1993, p. 7, original emphasis)

\section{The agent of responsibility}

This auto-emancipation which is an auto-constitution pretends that it can liberate itself from the anguish which provokes the trembling of being and from the vulnerability of the relation to the other. Lyotard argues that when 'man' owes nothing to the other: 'He liberates himself from the other by exteriorizing the other, then by attacking/seizing the other [en lui mettant la main dessus]' (1993, p. 8). This is starkly illustrated in the history of the conquest of America, and countless brutal episodes in the course of colonization, linking the 'othering' of the other to the 'knowledge that kills' and to dispossession and domination, as I will show in the next chapter. Derrida, for his part, examines the implications of regarding the other as the absolute other, for instance in the idea of God as such an other, or in Levinas's insistence on the infinite alterity of the other, linking it to the assumption of the absolute singularity of the other. ${ }^{5}$ To start with, it means the impossibility of distinguishing between the ethical and the religious, which renders incoherent the grounds for responsibility, for what principles, then, apart from the unconditional duty and the imperative to obey the law or follow the commandment because of its sacred \pm and thus secret, unfathomable \pm provenance, would ground responsibility in the immediacy of the face relation outside the disavowals inscribed in the imaginary of

\footnotetext{
5 See also the discussion of violence and metaphysics in Derrida (1967).
} 
transcendental discourses? If the law is the only limit which circumscribes responsibility, and if it is not possible to separate out the realm of the religious from that of the legal and the political, how is one to assign responsibility when it is a matter of judging the societies which, for example, allow millions of children to die of hunger (so that the affluent may eat well), this 'sacrifice of others to avoid being sacrificed oneself' (Derrida 1995, p. 86), organized as an integral part of these societies' own good order and well-being? The law of secrecy in Christian teaching (Derrida discusses Matthew 6: particularly the passages chosen by Kierkegaard at the end of Fear and Trembling) comes to be interiorized in the soul or the heart, so that the light of the good no longer shows itself as an external visible good but proceeds from an interior invisible source, motivating sacrifice as gift and as sign of goodness.

The elaboration of a notion of the origin and foundation of interiority as sacred and secret inaugurates religion, a mise-en-discours of being that diminishes the archaic dread by securing the individual to the closed space of a community, the closed space of its universe of meanings. The closure is removed from questioning by being established in the inaccessibility of a divine or transcendent will. Its erasure is exchanged for the promise of an eventual but transcendent fulfilment, a promise of Life. The only injunction is to have faith and to repeat the gestures of submission: believe and you will be saved, or, in the Althusserian model, submit and you will be recognized. Ready-made answers are provided there that repeat and confirm the intelligibility of the world in accord with transcendent foundations that remove individual will and intentions from the order of things: Thy will be done. Human destiny was literally in the lap of the gods, though responsibility for one's action in the world, especially in the Semitic religions \pm Christianity, Judaism and Islam \pm is returned to individual conscience. It is well to bear in mind that before modern times the question of what lies between the world of humans and that of the gods was the question that had but another question for answer; in other words, it was the enigma hiding a forbidden knowledge that doomed the questioner in advance to the fate always-already decreed by the Sphinx. Therein lies another aspect of secrecy, namely, that the secret is precisely that which must not be known: origin of the taboo, and the secret of the Law (of the Father) \pm which Oedipus transgressed.

The trouble with the religions of the Book is the abyss which is created between the sacrificial love bound to the love of the absolute Other and the caring love bound to filiality, and to the desired other. The former is tied to the notion of an absolutely inaccessible secret compelling us to a incalculable duty, including the sacrifice of oneself and one's own; the latter is grounded in another economy: the 'law of the home, of the family and of the hearth' (Derrida 1995, p. 88), requiring a different kind of listening and feeling. What I wish to bring out in my analysis are the connections that appear between finitude, beingness-in-the-world and the economies of the gift and of sacrifice. In the background, the question of emancipation remains, keeping visible the economy of desire which motivates it. The lesson I draw from the economy of sacrifice attached to monotheism and to a transcendent divine authority is its mutation in the secular discourse of modernity, particularly in its occidentalist form, whereby the disempowered and dispossessed 'other' is sacrificed, as an inevitable cost, in the name of the 'growth' and well-being of the modern social 
order as a whole. This notion of sacrifice, as I have noted, is expressed in the dictum of the civilizing mission of imperialism: we are your masters because we want to save you for a better future, by sacrificing your culture and way of life in exchange for the occidentalist gift. We find this idea of sacrifice in J.S. Mill's view of Indian civilization or in Balfour's 1910 declaration that Said (1978) interrogated. ${ }^{6}$ From the nineteenth century, salvation and emancipation are transformed into the promise of 'development' and 'modernization' presented as ultimate goods, the gift or reward of 'civilization' that will be bestowed at the right time, provided the colonized 'other' renounces her 'otherness' and acknowledges the law of Europe. Kant's prescription of a 'universal cosmopolitical state', as Derrida has pointed out, advocates the political unification of the human species and all nations under the aegis of European hegemony, when Europe would 'one day give laws to all others' (Derrida 1997, p. 22). For the 'developing' world, the moment of the right time is endlessly deferred, since it is ever in the position of the follower, catching up with the standards and norms of advancement always-already accomplished by the West.

\section{The colonial space of modernity and identity}

With modernity, or, rather, beginning with the secular narrative of being that started to emerge with it, there appeared a narrative that returned responsibility for destiny to human agency, specifically to the notion of the subject understood as origin of responsibility and free will, able to exercise an unconditioned freedom. Freedom amplified the existential angst at a time when the Europeans' discovery of what they called the New World was to change history for ever. Let me make two connections that will give an idea of the direction in which I want to pursue the interrogation of modernity and modern subjectivity, drawing on Derrida and Morrison. Two questions will indicate the general orientation of my analysis: How are we to interpret the birth of Europe and its metonymic relation with modernity? And does that conjuncture, that is, the birth and coupling of Europe and modernity, ground and limit the civilization enframed by occidentalism? Another consideration follows this line of inquiry \pm if, indeed, it does not precede it \pm raised by Derrida in his analysis of Jan Patocka's essay on the birth, expansion and future of Europe, which he had expressed in terms of an ailment which damns 'modern civilization' inasmuch as it is European, specifically, 'why does it suffer from ignorance of its history, from a failure to assume its responsibility, that is, the memory of its history as history of responsibility' (1995, pp. 3, 4 , original emphasis). Derrida goes on to point out that it is not a matter of insufficient knowledge, but that European historical knowledge 'occludes, confines, or saturates those questions, grounds, or abysses, naively presuming to totalize or naturalize them, or ... losing themselves in the details' $(1995$, p. 4). To avoid totalizing closure, or amnesia, the problem of history must remain open: 'History

\footnotetext{
${ }^{6}$ We find its pathological expression in the US military strategy in Vietnam, in the decision in favour of the saturation bombing of the land on the grounds that 'we had to destroy it in order to save it'.
} 
can be neither a decidable object nor a totality capable of being mastered, precisely because it is tied to responsibility, to faith, and to the gift' (1995, p. 5).

My interest lies in the conditions that overdetermined closure and forgetting the trauma and violence that motivate erasure and repetition. For that reason, I would like to reterritorialize the question on the terrain of occidentalism, that is to say, within the conceptual space enunciated at the juncture of the becomingWestern of Europe and the becoming-modern of the world. It is affiliated with the idea of modernity as the history of humanity in the singular and the idea of 'History' as the becoming-Western of humanity. Occidentalism, therefore, is the space of the co-articulation of logocentric reason, technocratic rationality and imperialism by way of an egocentric ontology of being. It inscribes the privilege of the West as the superior locus of world-historical development, and the modern Western subject as the agent of that process. My intention is both to deconstruct this space and to break with the imaginary it supports. My analysis is therefore located within the conceptual space of 'postcoloniality' since, as I explained in Chapter 1, that space is constituted in the process of the deconstructive critique of occidentalism; it attempts to imagine the beyond of occidentalism.

Robert Young makes the important point that colonialism 'constitutes the dislocating term in the theory/history debate' (1990, p. vii), a thought which I would locate, on one side, in the shadow of the ending of one form of global domination in the form of the imperial world order, replaced by more complex forms of subjugation and power, and, on the other side, in the longer history of the subject that I am trying to reconstruct by examining the conceptual shifts and breaks that transmute the more archaic search for an emancipatory meaning to human existence into the project of modernity. Young notes that there has emerged a politics associated with what one can loosely call poststructuralism which, like in Cixous's work, 'weaves capitalist economic exploitation, racism, colonialism, sexism, together with, perhaps unexpectedly, "History" and the structure of the Hegelian dialectic' (Young 1990, p. 1). This critique, whilst it targets the same oppressions as Marxism, operates a distance from it in its rejection of the classical Marxist view of history as the narrative of the unfolding of a rational system proceeding according to the logic of the (Hegelian) dialectic, driven by inherent contradictions. It is a world history, co-opting all other cultures into its universalizing stream. It is well to remember that it is the tendency within the logic of the dialectic to reduce the other to the same, through the concept of the Aufhebung, even when recognizing the other as the negation of the same, that produces the double bind of difference, namely, that difference is both necessary, as negation of the Same, yet it is transmuted \pm absorbed into the Same, or the One, through supersession. The uncanny resemblance with the logic of the logocentric subject means that the notion of a universalizing and totalizing History repeats what Cixous called the 'masculine Empire of the Selfsame' (cited in Young 1990, p. 3). At one level, therefore, the appropriation of poststructuralism within feminist and postcolonial (post-Black, post-Bandung, post-'Third World') politics joins with the dissident politics of opposition to phallogo-Eurocentrism, a politics, 
therefore, of the future as possibility, specifically the future as the becomingresponsible and becoming-ethical of humanity. ${ }^{7}$

Let me add another voice to emphasize this standpoint. In her powerful critique of American literary imagination, Toni Morrison (1992) makes a telling connection between the conditions that shaped people's lives at the time of colonization and slavery, and the writing that expressed European experience at the dawn of modern times. For the early Americans, this writing explores the encounter with the new forces and contradictions, translating the old fears and insecurities, tied to a memory of Europe, to the context of the new possibilities and risks that awaited in the New World. The literary imagination transferred the historical, moral, metaphysical and environmental fears inscribed in European culture onto the bound and violently silenced black bodies of a 'slave population that was understood to have offered itself up for a meditation on human freedom in terms other than the abstractions of human potential and the rights of man' (1992, p. 38). Indeed, 'Nothing highlighted freedom \pm if it did not in fact create it \pm like slavery' (1992, p. 38). The conjunction of blackness and enslavement enabled the 'not-free' to be tied in the modern imaginary with the 'not-me', producing 'a brew of darkness, otherness, alarm and desire that is uniquely American' (1992, p. 38). The point she makes about how in American literature the concerns of 'autonomy, authority, newness and difference, absolute power [became] shaped by, activated by a complex awareness and employment of a constituted Africanism' (1992, p. 44) can be extended to apply to the relationship between modernity and colonialism generally. I draw attention to this connection in order to make clear that the refiguring of modernity is not a matter simply for the 'West'. Colonial enterprise introduced a new scale, an excessive scale \pm vast expanse of brute nature, unknown cultures, uncharted territories \pm against which the emergent modern subject could measure its (in)significance and its potential grandeur. The becoming-modern of the world which colonialism and imperialism accomplished over the centuries makes the question of what, and who, comes after modernity and after occidentalism a question that concerns everyone.

We need, however, to rework the terms and the terrain of the debate. The two most familiar targets concern the notion of reason privileged in a particular Enlightenment discourse and the notion of subject inscribed in the 'philosophy of the subject'. The work of critical theory, especially in Adorno, Horkheimer, Benjamin and Habermas, has already demonstrated how a totalizing reason allied to a universalizing History tends towards domination and totalitarian and terroristic forms of governance. But the question is not so much what has gone wrong; rather, it is the recognition that these tendencies were intrinsic to the worlding of the world that colonialism and modernist imperialism instituted. The case of Nazi fascism and the Holocaust will allow me to indicate the displacement in the analytical gaze which the postcolonial standpoint operates. Already, Fanon, quite some time ago, had

\footnotetext{
7 My choice of language evokes a resonance with the goals of Enlightenment philosophy, which might be thought surprising. What I have said so far should indicate, however, that the interrogation of the concept of 'History' and of the discourse of the Enlightenment is far from being peripheral to postcolonial critique; they are indeed central to it.
} 
drawn attention to the view that fascism can be seen as the returning home to Europe of the despotic impulse of totalizing reason. Indeed, it could be argued that the fact that Germany did not participate, initially, in the imperial enterprise, that is to say, the fact that it did not bind the notion of the nation and measure its greatness and validate its progress by reference to a global project, that is, by reference to an exteriorization of the nation's will and agency projected onto a universal scene, meant that it had to find within itself the proof of its maturity and advancement. For European nation-states like France, England, Spain, imperial success and the exercise of a subjugating power acted to confirm the tropes of progress and greatness. Germany, in spite of becoming a great power in the nineteenth century, had instead to find within itself the signs of progress, it had to turn to its own 'essence' to discover the qualities that would exemplify the superiority and authenticity of the race. The proof of these qualities could only come from acts and achievements that, in taking Germany itself to be the object of its project of emancipation and aggrandizement, brought about the instrumental becoming of the nation as the authentic race, the promised race. The totalizing and narcissistic nationalism which the absence of an external empire provoked in the period of fascism has affinities with and kindled deep-seated feelings, nurtured in the course of German history, that for a long time tied Germans to the soil and to community, to a sense of home (Heimat). The fact that Germany as nation-state was of recent, Bismarckian, foundation only amplified the investment in mythical origin and in the fantasmic character of the authentic, pure race. We know the extent to which the unity and authenticity of the race was performatively staged and embodied in the mass demonstrations of the spectacular folding of the community upon itself in its specular (mis)recognition. The public square became the cathedral sacralizing the authenticity of the race, thrust together by the force of the lack which drove it there. There, in the sight of its icons, the communal host pledged itself to its historical destiny. In the previous chapter, I pointed out the logic which bound this excessive desire with the violence of the Holocaust. An economy of sacrifice is at work there too. Fundamentalism today has often repeated these gestures and stratagems. My analysis shows that postcolonial deterritorializations can open up a space from which to rewrite the history of Europe, and to question the categories and epistemologies that have authorized the occidentalist narrative of modernity as a project of the becoming of humanity as universal History. The same displacement opens up the history of the present to a renewed reflection on the relation linking responsibility to historicity.

The question of the subject is less clear, for although the critique of logocentrism points to its complicities with a totalizing reason, that critique by itself does not provide ways of refiguring the question of the 'who' of action and the problem of agency. In particular, from the point of view of a politics of difference, that is, a politics that does not wish to subsume the interests and difference of the other into universal categories, problems emerge that concern the grounds of a different discourse of being that would eschew ontological and epistemological violence. The work of Levinas, as well as philosophies that draw critically from the phenomenological tradition generally, has appeared to provide a new point of departure. It is the terrain that my own exploration will develop in search of a position that refuses the supplementarity of the 'other' \pm woman, the non-European and non-white \pm in 
the elaboration of a narrative of emancipation. The question is how to respect the alterity of the other without essentializing difference and without grounding ethical principles in the terrain of the philosophy of the Same and an economy of sacrifice. ${ }^{8}$

\section{On subjectivity}

Let me, for the sake of argument, start with the idea of the 'I' as a (non-Husserlian) epoche, that is to say, the idea which develops the view that the constitution of the 'I', as a point of subjective reference, describes the emergence of a position in language and in speech which gathers to itself and is itself the resultant of an historical process of formation whereby an originary intentionality and consciousness are 'made real': as the place from which speech issues and as the location of agency. The 'I' would be the place-marker for presence, in practice the presence of a particular self, or the place from which a named person enunciates itself as the one who is called to responsibility: I, Abraham. ${ }^{9}$

The point of using a term like epoche is that it enables me to inscribe the spatial and temporal dimension of subjectivity in a theorization that respects the historicity of being. What it does not do is signal a break with the problematic of the 'I' as origin or final destination of the process of constitution, as arche or telos, that is to say, the problematic of presence. The move away from this way of conceptualizing subjectivity makes us recall that Derrida invented the term differance to point to temporization and spacing and their conjointness in the process of signification. The question of the 'who' is implicated as soon as we speak of signification. However, we would remain on the terrain of the 'I' as unitary singularity if we were to prioritize the question of the 'who' before immediately examining what the implications of differance, and temporalization and spatialization were, from the point of view of the other, that is, if we thought that the question of subjectivity could be answered prior to the theorization of the relation to the other. ${ }^{10}$

For that reason, I will propose that 'I' and my other belong to the same epoche: an I by itself does not exist. This is the basic proposition of heteronomy; it implies that there is a double differentiation and a double inscription in the process of institution of an 'I'. I shall examine this proposition below. First, I want to point to what I am leaving behind in this approach. To begin with, I am breaking with the metaphysics of presence, that is, the idea of the 'I' emerging as the result of a process of the doubling or folding of the 'I' upon itself to constitute an absolute interiority, an interiority that requires reference to no other except itself, its own process of cogitation: the I who is the seat of the cogito: I think, therefore I am.

\footnotetext{
${ }^{8}$ It follows from what I have said that this economy covers both self-sacrifice, as in Puritanism, and the sacrifice of the 'other' for the sake of bringing about a universal cosmopolitan identity.

${ }^{9}$ My understanding of the concept is clearly different from Husserl's (1970), although informed by that problematic and subsequent discussion, for example, in Ricoeur's (1992) inflection of the concept towards the 'who' rather than the 'what' or the 'why' of action.

${ }^{10}$ Psychology, and the social sciences generally, do this; it is an assumption which is in keeping with the manner of the birth of the modern subject, as I will explain in Chapter 3.
} 
Second, I am breaking with Lacan's version of the emergence of the 'I'. For Lacan (1966a), the mirror stage is a three-term series or process involving the 'real', the imaginary and the symbolic, out of which the 'I' emerges. Lacan does posit the relation to the other as vital, for it is in the moment of splitting from the other that a being accedes to subjectivity, as a singularity, carrying the burden of an irrevocable loss (of the other, and of the object). With the Lacanian problematic, the 'I' imagines itself to be as it fantasizes the other to have constituted it. In other words, it is an 'as if' recognition, shaped by the wish and by desire and thus condemned to misrecognition. In the process, the real too becomes embroiled in the same distorting mechanisms of the mirror stage, caught in the endless shunting between the imaginary and the symbolic, yet functioning as the necessary third term that binds all three moments of subjectivity. The assumption of an inevitable misrecognition supports a pessimistic thematic of being, blind to the joyful aspects of the process of emergence of the ' $\mathrm{I}$ ' into selfhood, prioritizing instead the traumatic elements of the experience. In this economy of subjectivity, the trauma of the (conjectured) Oedipal drama leaves traces that cannot be erased, and which must bind me to the Law and to a particular libidinal economy. I am, of course, bracketing the Freudian account which reduces the economy of desire to that of sexuality and to the space of the libidinal scene and its psychic consequences. To the ontological poverty of this reduction must be added the well-established phallocentrism of Freudianism's account of female sexuality and the implications for gender difference (Deleuze and Guattari 1985; Irigaray 1984). Apart from the privilege of sexuality \pm is this JudeoChristian too? \pm the problematic of representation in non-Lacanian, non-feminist psycho-analytic theory, although subversive of the cogito and clearly not realist, does not break with egocentric assumptions. What follows is an attempt to construct a conceptual space which secures such a break.

\section{Folding}

Within the social sciences, the elaboration of the mechanisms that operate to constitute the 'who' of subjectivity follows some fairly well-trodden paths, which take for granted a self-centred subject, and which aim to explain 'behaviour' by reference to a science and what this assumes about the object of knowledge. The basic approach is framed by the model of a social outside that gets inside the subject through processes of 'socialization' or by means of a psychologization of the individual. I shall not engage with this model, having done so elsewhere (Henriques et al. 1998 [1984]). One approach which appears to undermine subject-centredness follows Foucault in accounting for the subject in terms of effects produced by apparatuses of formation, disciplining, normalization and regulation of the social and of the subject. We would of course have to add to this account the explanation of how the sense of a 'who' as an interiority comes to be constituted, either as part of this process of formation or as something requiring, in addition, a 'regime of the self', instituted in techniques of self-inspection and in 'self-steering mechanisms', informed by particular discourses and codes that provide each person with the discursive and practical tools for judging her/ himself. For example, what does it mean to be a good 
parent? How do I know that I am doing the right thing as a parent? What authorizes the practices that I am supposed to follow? Within a Foucauldian analytic, a genealogy of the discourses and the practices of parenting from the nineteenth century would establish the range of technologies and normative discourses and their mutations that, since the emergence of the sciences of the social, have operated in the process of formation of the subject as the good parent.

This range of technologies of the social is nicely detailed by Nikolas Rose (1996), who adds several remarks that locate the problematic of subjectification beyond the models of socialization or psychologization of the individual. Rose recognizes the reference to an interiority in histories of the self, but proposes the view that interiority is the result of the "infolding of an "exterior" to constitute an 'inside' or soul (1996, p. 142). Furthermore, the infoldings are 'stabilized' in two ways: first, the functioning of a biography which articulates the relation we have to ourselves in the form of a narrative or memorization of how we think we have come to be the person we are; and, second, by reference to the relation we have with the spatial dimension of being. Human beings, he says, are 'emplaced, enacted through a regime of devices, gazes, techniques which extend beyond the limits of the flesh into spaces and assemblies' (1996, p. 143). The spatialization of being and the narrativization of being are conjoined processes, producing the human being as 'a hybrid of flesh, knowledge, passion and technique' (1996, p. 144).

Let us see how this position might direct our gaze when we look into the case of the constitution of the good parent. We could then examine what is left unaccounted for. We recognize, to begin with, that the human technologies, both disciplinary and pastoral, that participate in the process of formation have a genealogy that we can reconstruct as a history of strategies, purposes, normative orientations and so on, that have become codified, instrumentalized, institutionalized and routinized, inscribed in the spatial and temporal lifeworld, distributed as know-how and expertise amongst agents and agencies that function to bring about desired ends. The parent is located within these already constituted 'hybrid assemblages' (that are open to variation and change over time); s/he becomes apprenticed to a stage of formation. S/he encounters advisers and experts, like doctors, nurses, health visitors, in a variety of sites like clinics and hospitals, nursery schools and creÁches which have been disposed in such a way as to structure the relations of power and authority and the encounters that can take place. We go to such places with the 'right' attitudes and with particular expectations, including the willingness to accept the authority of those vested with the power to advise and guide or judge. The system of authority is supported by texts and child-care manuals and magazines that prepare us for the 'role' of parenting. There exist too a whole range of equipments and objects, books and toys that provide the material support for the practice of bringing up a child, without which it would be impossible to translate codes, rules and know-how into a routine of tasks and behaviours and communicative action. Every parent constantly scrutinizes her/himself, not only checking out whether s/he is following the proper procedures and methods, but also judging her/his level of commitment and effort, her/his willingness to learn and improve, inspecting secret desires and guilts. In this way, each of us constructs ourself as a parent and reconstructs the relation we have to ourself. 
Rose's analysis of the modern process of subjectification ends with a number of remarks about the rationalities of the new machinery of the governance of oneself and of the social which is now appearing. He points to 'new ethical vocabularies', valorizing notions of autonomy, choice, enterprise, lifestyle, that may well be establishing new 'dividing practices', 'new modalities of folding authority into the soul' (1996, p. 145) and new forms of self-government grounded in 'rationalities of contracts, consumers and competition' (1996, p. 146). For Rose, it is possible to gain a critical purchase on these mechanisms by way of historical explorations that can 'unsettle' established forms of subjectification. This development is relatively familiar territory for those who are trying to rethink our presentness in the light of the work of Foucault.

Yet, I cannot help thinking that there are other key elements of beingness that exceed the apparatus of formation and self-formation that I have sketched. I am going to try to discuss them by reference to the groundedness and the 'groundlessness' or, rather, ungroundedness of our being in the world. To begin with, it seems to me that we need to be able to account for the fact that a new experience like parenting \pm or, indeed, living with a partner, or settling in a different country, and so on \pm significantly reshapes our biography, occasioning the revaluation of previous relations, for instance with parents, partners, friends. Such events result in engagement in a whole new range of activities tied to new locations like schools, communities and organizations like child-care groups, with the result that our orientations and concerns, our expectations of ourselves and our life-projects become altered. An additional source of knowledge and value derives from friends and relatives with whom we compare and exchange experiences and stories and reflect upon our conduct both as a parent and in relation to a biography that includes the reactions (for instance of approval or disapproval) and the expectations and demands of others. Thus, the process of formation and change of particular 'identities' involves, in addition, interactions that, although regulated by ad hoc steering mechanisms, are relatively unstructured and open to negotiations based on friendship and trust. At the end of this process of refiguration, we have different and new kinds of stories to tell about ourselves; we are in a sense no longer who we were before.

All of this change has to do with the grounded character of selves and with something else that in part relates to the question of an 'ethics of the self', that is to say, the (culturally and historically specific) relation to oneself that we develop in relation to particular corporeal, intellectual and hermeneutic or self-reflective regimes, which guide us in the ways we are supposed to walk, talk, eat, dress, make love, think, plan, reflect upon our actions and motives, and so on, as part of coming to understand ourself as a particular individual. I say in part because the extensive recent literature on the fashioning of the self has not sufficiently broken with the perspective of the singularity of the self. I want instead to point to the view that 'selfsteering' and 'self-fashioning' devices are not merely heuristic devices; the way they work involves more than the infolding of an exteriority to constitute an interiority, more than a particular form of learning to be the person we become. In the example of parenting, it is significant that the technologies of subjectification are given a practical realization as part of relations between persons, minimally between the child and a parent, more routinely as information, knowledges, opinions, anecdotes, 
reflections and questions that are exchanged in episodes of communicative action involving children, friends, relations and authorized advisers and agents, often occurring in sites that are relatively open spaces like the schoolyard and the neighbourhood or the cafe and the pub. In this way, general, abstract rules and knowledges and ways of doing are translated into a social reality involving the face-to-face interaction of associative communities. The process describes the social institution of the lifeworld. A domain of inter-subjectivity mediates the application or functioning of the devices and apparatuses of subjectification, inflecting the meanings and values we come to attach to particular experiences and thoughts; for instance, we trust the opinion of a particular doctor or expert more than that of another. Ideally, the process of subjectification works best when it appears to be the result of unforced choices and wills. In any case, visible power or power lived as imposition sets up resistances and tactics of evasion that undermine normalization and challenge normative principles.

\section{Bonding}

The processes of self-formation must be seen also as ways of bonding with particular others, ways of building trust and solidarity, that is, ways of establishing one's 'self' in terms of particular durable relations to specific others, at the same time as in terms of the relation one has with oneself. The one implicates the other in the form of a double inscription. For example, we can say that the work we do upon ourselves to become a parent is integral to the work we do in constituting an infant as a particular subjectivity; the two subjectivities grow together. Let us think of it as a choreography, a process of learning to be one with the other, with the complex baggage of narcissism, seduction, identification, pleasure, separation and pain which accompanies this complex elaboration of individual identities. The grounded dimension of being, then, refers to the range of mechanisms, devices, discourses and sites involved in these processes, as well as the embodied interactions in relational encounters that together enact the practice of everyday life and constitute the materiality and the inter-subjective reality of the lifeworld.

Let me add another dimension to the question of subjectification which emerges when we recognize its enigmatic character, and which obliges us to relate the groundedness of being to a transcendent or liminal domain. This presencing of something unpresentable in the space of the 'happening' of being harbours a seemingly timeless dimension, irreducible to ground and so to technologies, yet paradoxically finding its support there. A thought of Levinas (1969) will allow me to present one aspect of the kind of questioning that $I$ have in mind. It is the distinction which he makes between the saying and the said. In the relation to the other, the saying concerns the 'face relation', that is to say, it occurs in a situation that places us in a position of absolute responsibility for the other, open to the silent demand of the other, thrown into a relationship beyond the rules of contractual arrangements or reciprocal obligations. Intimations of an infinite measure surface here to point to a reflection about foundational principles to which I will return. 
I would like to indicate this other dimension by turning to a number of texts where we discover a different kind of discourse, a different relation to oneself which events like becoming a parent produce. It is a relation that cannot easily be brought within the compass of the framework of governance or of the idea of the emergence of an interiority by reference to the infolding of a describable outside. Listen, for example, to Kristeva (1983), who in the essay 'Stabat Mater' pursues and links several themes concerning the maternal body and the fleshy and 'spiritual' lived relation to the foetus and the infant. In this instance, she uses this relation as a basis for a meditation on the place of the different figures of Mary in the Christian discourse of emancipation from finitude and from death. She proposes the idea of the 'humanization of Christianism' from the fifteenth century through the (older) cult of Mary, thereby linking the theological arguments about humanism to changing representations of the feminine in the West and to the theme of love and ethics. She argues that none of these strategies of language can exhaust the 'unsaid' and the unsayable about the maternal body:

$[\mathrm{N}]$ o signifier can exhaust it without remainder. ... As much as it is concerned with each woman's body, this heterogeneity which cannot be subsumed by the signifier is nevertheless violently fractured by pregnancy (basis of culture and nature) and with the arrival of the child (which brings a woman out of her unitariness and gives her the chance \pm but not a certainty \pm of access to the other, to ethics). These particularities of the maternal body make of a woman a being made up of folds, a catastrophe of being that the dialectic of the trinity and its supplements cannot subsume. (1983, p. 245)

The phenomenology of the invisible relation of the foetus/infant with the mother, which Kristeva transcribes in the marginal text of 'Stabat Mater', as its supplement, bears interesting comparison with Irigaray's account of the mother/child dyad specified in her work And the One Does Not Move without the Other. The title functions as the index of a double economy of identity whereby the one comes to define itself by reference to the other, so that the subject is more than one but less than two, exceeding singularity yet not abolished in the process of identification. The relation of the subject to its other is analogous to the relation of the visible to its invisible side. Consider, for instance, this passage: 'If I leave, you no longer find yourself. Was I not the deposit that secures against your disappearance? The placeholder for your absence?' (1979, p. 16). Or this: 'And why should some other wound have been imposed upon me? Did I not already have my/your lips? And this body open to the gift that never could we have finished giving each other. To speak each other' (1979, p. 21). The intimacy of the writing here and in the rest of the text should be set against Irigaray's (1984) reflections about the ethics of sexual difference. What then comes to light is the attempt to relate the economy of selfhood or 'identity' to the economy of the body \pm beyond sexuality and gender, but not excluding them, taking its cue from Merleau-Ponty's The Visible and the Invisible (1968) \pm and the economy of the gift. It is when we proceed in this way that the invisibility of what lies in the shadows of technologies and machineries of subjectification alerts us to the other dimension which I have signalled. I shall develop this connection below. 


\section{Desiring}

For now I want to add other texts and authors to make visible the kind of reflection about our beingness in the world, our groundedness in the here and now, that, starting with some defining moments like engendering another being or caring for an other or loving and giving, provides the occasion for a meditation on the ontological, ethical, epistemological and existential questions that an examination of the machinery of subjectification does not in itself yield. They are not, for all that, questions that we can simply relegate to specialisms or ignore on the grounds of arcane philosophical interest. There are many and different paths one could follow to pursue the exploration which I am proposing. One approach is to limit its interrogation to the performative character of the technologies that, in the modern form of sociality, constitute a subject as subject of particular regimes of behaviours and reflections. Another recognizes the limitations and insufficiency of discourse, and of the letter of the law, to voice the unsayable, or to provide readymade answers to the experience of the abyss: lack, finitude, loss of the other or the object, temporality and historicity of being. There has existed for a long time a third way, buried in the history of being, namely, the stratagem of deferring or banishing the anguish and terror of the indefinite and indeterminate by fixing the discursive grounds of such questioning to unquestionable principles or dogmas functioning as transcendental guarantees, putting them beyond what is open to question and doubt. Many people find this route in religion, and, increasingly, through the securities and totalizations of fundamentalism.

One set of considerations that I want to put on the agenda concerns the positivity of desire, the pleasures of the body, the search for plenitude and the promise of joy, something fundamental to being that the social sciences and rational reconstructions of historical periods and the formation of subjectivities do not fathom. I should include amongst the latter the Hegelian analysis of the relation to the other in the emergence of consciousness or the emergence of the self as a differentiated self; the master \pm slave thematic, in particular, proposes a model in which the recognition of the other is instrumentalized into the tactic of the objectification of the other for the subject's own ends. I side-step the Hegelian problematic because I want to focus on a line of thought that implicates a longer genealogy of the subject of which the subject of modernity is but a segment. It aims to join ontology and phenomenology, seeking something of lasting value in the passing moment, to paraphrase Baudelaire.

A good deal of important work on the embodied character of subjectivity has been done within feminist theory, for example, in the work of Irigaray or Cixous generally, and specifically in Grosz (1994), Braidotti (1994), Gatens (1996), and Butler (1990, 1993). The lessons from this corpus concern the subversion of the tired dualities in Western thought between mind and body in which mind is privileged, and the consequent neglect of the 'unruly', 'disruptive' body that must be tamed by masculine reason. One consequence of dualism has been the removal of consciousness 'from direct contact with other minds and a sociocultural community' (Grosz 1994, p. 7). The project of 'contesting the domination 
of the body by biology' obliges us to 'rethink the opposition between the inside and the outside, the private and the public, the self and the other' beyond forms of essentialism and originary centrings (Grosz 1994, p. 20). Grosz thinks the relationship between nature and culture in terms of 'interimplication', marked by difference and the logic of reciprocal supplementarity. The rejection of dualism, historically reduced to oppositions, draws attention instead to the point of view of an embodied subjectivity and 'psychical corporeality'. The body is constituted as both material and psychic space incorporated within the lifeworld. Grosz suggests a concept of human materiality that implies continuity between it and organic and inorganic materiality; it is a materialism beyond physicalism. An implication is that 'corporeality must no longer be associated with one sex (or race)' (1994, p. 22). One would need to imagine 'a plural and multiple field of possible body "types"' (1994, p. 22), such that the body functions as a threshold concept between binary pairs \pm male, female, say \pm problematizing them (1994, p. 22). Thus, the body 'is neither \pm while also being both \pm the private or the public, self or other, natural or cultural, psychical or social, instinctive or learned, genetically or environmentally determined' (1994, p. 23). Later, in Chapter 5, I will establish that the body is the 'primordial ground' of being (Merleau-Ponty 1968), and that it exists as monument in the sense of memory embodied, spatialized and temporalized in the world of objects.

The fundamental problematization of embodiment and subjectivity is differently pursued in the work of Butler, where she grounds the discussion in issues of gender and sexuality as sites for troubling phallogocentrism and challenging the limitations of positions (for instance, Foucault, constructivism) that, whilst radical and subversive, have started to reveal lines of fracture in the light of more recent subversions. The problem has been the question of allocating the share of cultural determination against the claims of critical agency without which one cannot imagine counterhegemonic acts of dissidence or opposition. Perhaps it is a matter of rethinking the concept of constitutive construction, so that it is understood as a constraint limiting the process of normalization and stabilization of subjectivities. Then we could think that bodies 'only appear, only endure, only live within the productive constraints of certain highly gendered regulatory groups' (Butler 1993, p. xi). The constitutive process involves both material and discursive practices. The two are articulated in the performative instantiation of a norm in a practice, provided one understands performativity as 'the reiterative and citational practice by which discourse produces the effects that it names' (Butler 1993, p. 2). As an illustration, one could think of the acts and signifying practices through which a subject recites itself as racist or heterosexual, that is to say, repeats through gestures and speech the regulatory norms which materialize a particular 'identity' in a body. The body, in Butler's theorization, is always-already materialized, it is not the blank slate upon which discourse writes the subject; rather, it is always in the process of formation and reformation as effects of relations of power. The question of identification, whereby a particular subjectivity emerges, is tied up with the performative character of regimes of instituting particular normative and normalized ways of being. Power operates in these mechanisms at both the material and discursive levels, so that, concerning specific dimensions like sexuality and gender, 'the symbolic ought to be rethought as a 
series of normativizing injunctions that secure the borders of sex through the threat of psychosis, abjection, psychic unlivability' (Butler 1993, pp. 14, 15). The symbolic thus appears to have the force of 'law', though what is 'forced' 'is a citation of its law that reiterates and consolidates the ruse of its own force' (1993, p. 15). This designates also, presumably, the coefficient of its effectivity, when we remember that Foucault thought that power was the more effective the more it could conceal its operation as power. Butler identifies the agency inside the process of citation of power, so that transgressive subjectivity would be constituted inside the relations of power and not outside them. One can see how the risk of invoking a voluntarist agent when it is a matter of resistance motivates a theorization of constitution that tries to locate both the normative and the transgressive inside the field of operation of power, though one then has to differentiate power \pm so that it is not the same power or the same mode of operation of power or the same target that is involved \pm and heterogenize the domain of the symbolic, as agonistic sites producing mobile, polyvalent subjective positions. Or one could locate such sites when considering cases like the implantation of Western culture in the colonies through the apparatus of schooling. Bhabha's (1994) analysis of mimicry in India or Trinh Minh-ha's (1989) exploration of uncolonized spaces in subjugated cultures in South-East Asia, and Appiah's (1992) uncovering of the practices of resistance to British rule in Nigeria show that resistance and transgression are conditioned by prior diffractions of power, so that power itself must be pluralized, here between colonialist subjugative power and indigenous authorizing narratives and narratives of identity inscribed in subaltern forms of sociality and memory. So, when examining the performative effects of subjectifying power, one would still have to posit relatively uncolonized arenas in the process of formation, for instance in Foucault, 'bodies and pleasures'. This point is taken up by Butler (1999) when she examines the break away from 'sex-desire' to 'bodies and pleasures' in Foucault's problematic of sexuality, where the latter is made to counter the force of subjugating power in prescribing a normative sexuality, thus normative gender relations, and the consequences of that shift from the point of view of social regulation. A difficulty is that the tactical reversal of regulative sexuality through the agency of bodies and pleasures implicates a different register for thinking agency, one that is not clear in Foucault, for how can there be uninvested spaces, or spaces that are not immediately co-opted, or spaces that exist in a new time yet to appear? Foucault's thinking about this, and the element that Butler exposes, is that desire demands a separate history, tied to a genealogy of the subject which addresses the question of how and why the subject has come to understand itself by reference to the notion of a desiring subject. As Butler points out: 'To deny the sphere of desire, or call for its replacement, is precisely to eradicate the phenomenological ground of sexuality itself' (1999, p. 19). The way out of the quandary is to turn to the question of historicity and the problematic of narrative identity, which I will introduce below.

There is another set of considerations, still in answer to the question of our 'presentness', that opens up the question of 'identity' and subjectification in some unexpected ways. I am thinking of the problematic of resistance to colonial forms of subjection/subjectification and of the disjunctions that operate to fracture subjectivity in that field, and that reveal the imbrications of power in the process in a different light. 
They add to the problems that emerge when we try to think through the historically contingent features of the constitution of subjects with respect to the institution of particular forms of the social world, problems which relate to the complexity of the process of constitution and its underdetermined character. My approach is to consider the constitution of subjects in and for modern imperial power and its form of governmentality. There are two lines of argument which motivate such an approach. As I argued in Chapter 1, the legacy of this history still operates in the social and cultural spaces territorialized by colonialism and imperialism, particularly in the technologies and apparatuses \pm for instance, the educational system \pm of the constitution of forms of sociality and of the regulation and administration of populations. The consequences, though diverse and ambivalent, have often been disastrous from the point of view of resistance to the occidentalized and capitalist models of modernization and by reference to the failures of these models which today increasingly provoke a turn to fundamentalism.

The other reason brings up one of the basic propositions that I am developing in the book. It concerns the claim that a way of locating the specificity of the modern discourse of the subject is to regard Europe's discovery and subjugation of the New World and its peoples and cultures, and the colonizing project as a whole, to have been one of the vital conditions which shaped that discourse. I shall develop this view in the next chapter, where I will examine the displacements and the transformations that stage the birth of modernity and its subject. The historicity of our presentness is made up of the intertwined genealogies of modernity, subjectivity and colonialism. Capitalism binds them at strategic points, acting as a chain, although the history of capitalism is not itself independent of the other histories.

Let me use the work of Fanon as a point of entry into the range of problems that I want to explore. There is a classic incident recalled in Black Skin White Masks in which a little white boy, upon seeing Fanon in France, points him out to his mother and exclaims 'Look, a Negro!'; and again 'Mother, see the Negro! I'm frightened!' (1970, p. 79). Fanon uses this incident to develop a meditation on blackness and to reveal the crisis of identity, an already fragile identity, which the gaze of the other precipitates when the gaze is structured not by the face relation but by the dread of the stranger as the racialized other. He at first reflects on how his carefully nurtured cosmopolitan persona, nourished by all that 'civilization' has to offer, is annihilated in the moment of being identified as the bogey-man of racist myths and stereotypes. The reiteration of naming: 'Negro', the pointing which interpellates Fanon, at first not quite believing he is the subject of the citation in the position of the frightening 'other', the boy's bodily gestures, expressing fear, distance and exclusion, all these mechanisms, at once discursive and embodied, performatively lock him into an identity he thought his formation as intellectual had cancelled. ${ }^{11}$ In that moment,

\footnotetext{
11 As I pointed out above, Butler understands performativity thus: ‘[p]erformativity must be understood not as a singular or deliberate "act", but, rather, as the reiterative and citational practice by which discourse produces the effects that it names ... [it is] that power of discourse to produce the phenomena that it regulates and constrains' (1993, p. 2). This privilege of discourse, it must be said, is affiliated to the problematic of representation, which conceals a nostalgia for another privilege: that of the logocentric subject ...
} 
Fanon discovers that his body had been given back to him 'sprawled out, distorted, recoloured, clad in mourning' (1970, p. 80). Skin is the intransigent barrier, the marker of a 'racial epidermal schema', laden with what he interestingly calls 'historicity' (1970, p. 79), and carrying the inheritance of narratives of native excess and violence. He feels unable to escape the fact that he is held responsible for his body, his race and his ancestry. The black body is already inscribed in a chain of signifiers locking the 'black' subject into a discursive field in which the metonymies of savagery and inferiority are repeated along the colonizer's historical narrative of race and colonial subjugation. It is a narrative that Fanon recites in his trawl through the occidentalist discourse about black people. Fixed into position by a history outside his control, Fanon wants to know how one could come to terms with the dislocations and the splittings inscribed in the black body, and still be a man.

Anonymity and invisibility do not help, they do not dispel the terror of being overdetermined and fixed in an unlivable identity. The strategy of a search for the recovery of a different self, not amputated and objectified, at first takes Fanon back to the narratives of blackness, refigured in the discourse of Negritude, celebrating a 'primitive mentality', the rhythms of which the tom-toms of memory beat into the body of the black man. He remembers too the narratives of the achievements and triumphs of Africa that colonialism had erased and its irreducibility to the debilitating abstractions of Western philosophy: 'From the opposite end of the white world a magical Negro culture was hailing me' (1970, p. 87). One is reminded of Benjamin's perceptive remark about history when the danger of subjection to the 'ruling class' is revealed: 'To articulate the past historically does not mean to recognize it "the way it really was" (Ranke). 'It means to seize hold of a memory as it flashes up at a moment of danger' (1973, p. 257). The strength to continue to resist, the resilience of the spirit that the black man needs to combat the accumulated burden of subjection, has to draw from something less totalizing than Western theory, from 'an almost substantive absoluteness' (Fanon 1970, p. 94). So Fanon turns to the poetry of Negritude to find the vocabulary and the voice in which to articulate the mixture of pain, rage and hope that assails and drives him. This is because writers like Senghor, Cesaire, Roumain, Wright, Diop, whose texts he cites, point to the polyvalence of 'Blackness', dissolving the white, univocal category of 'otherness', and strive to make visible the memory of Africa 'like a splinter in the wound'. They share with Fanon the desire to transmute the suffering of abjection into a world-transforming project. Their poetics is steeped in a barely legible past and in the body as the irreducible experiential core of being, attempting to make present or to bring to presence a future whose becoming would abolish the horror of the present.

Fanon's text, like those of Irigaray and Kristeva, but for different reasons, refers to a poiesis in the effort to apprehend the unpresentable dimension which no rationalized account can deliver to consciousness. It also brings to the fore the issue of the effects of power in the constitution of subjects, particularly the way antagonistic narratives provoke dislocations in the temporal and spatial dimensions of the 'lived' that are experienced as splittings, double-consciousness or even schizophrenia. Indeed, several themes can be picked out from the texts of these authors that I will explore through the concept of narrative identity. They concern the theorization of the body, the place of memory and of historicity in the formation and transformation 
of subjectivities and their stability or instability, the economy of desire, the problem of the narratives that constitute the 'reality' of the lifeworld.

\section{On the narrative character of identity}

I will start with the arguments that consider temporality to be the defining characteristic of human beings. In a very fundamental way, time determines the horizon for any understanding of being. As soon as we think of ourselves as conscious beings, we think time, and we cannot think time without bringing up the question of consciousness, specifically, the consciousness that we exist in time, stretched out between a remembered past, an evanescent present and the anticipation of a future. We know ourselves to be fateful and fatal beings, judging our presentness by reference to the spacing and trace of time. Like Heidegger, Ricoeur considers the havingbeen, the making-present and the coming-towards to be the three moments, indeed, the co-articulated moments of the temporality of being; they mark the space in which we question ourselves as to our way of being.

Yet, a basic aporia of time is its inscrutability. This may well be because we are encompassed by time. The avenue that Ricoeur follows is to explore the possibility that narrative is the form in which we can overcome the unrepresentability of time (when we think of it in the singular), and the device by which we express the lived aspect of temporality. The underlying idea is that the act of telling a story 'can transmute natural time into a specifically human time' (Ricoeur 1984, p. 17). In Ricoeur's approach, the term 'narrative identity' seems to join up two problematics: one which is about subjective identity and the other concerning the relation of history and fiction in the process of the figuration of temporality. It does so by establishing that time, and the way it is lived, provides the common ground for their co-articulation. Ricoeur draws a distinction between identity as sameness (idem) and identity as selfhood (ipse), that is to say, on the one hand, identity as something that remains identical to itself over time and, on the other hand, an entity that considers itself to remain the same being in spite of changes over time, for example, in a person's biographical history. Identity is not the sameness of a permanent, continuous, immutable, fixed entity; it is instead the mode of relating to being that can be characterized as selfhood. Self is not a fact or an event, it is not reducible to the facticity of things-in-themselves (or Heidegger's ready-to-hand). The identity of a person, or a group or a people, takes the form of stories told. Narrative identity, however, should not be understood as another name for biography or as a way of talking about the interiorization of the stories of a life to constitute personal identity. Indeed, Ricoeur's analysis is primarily located not on the terrain of a psychology but on that of ontology. Narrative identity appears in his discourse of being as the concept that enables us to think of the mediation between the phenomenological and the cosmological apprehension of time. Narrative is thus the way of joining up the 'time of the soul' with the time of the world. In a sense, the 'self' as a meaningful and meaning-making entity appears at the point of intersection of two kinds of reflection on our beingness or existence. On the one hand, we find the stories and memories that express the time of being-in-the-world and of being-with, the 
duration of events and experiences in the everyday: the time it takes to do countless mundane things at home or at work, and the time it takes for our children to grow into adults, the time of birthdays, commemorations, the scansion of temporal flow in every life. The cultural specificity of this experience of phenomenal temporality is a matter that is too often neglected in Eurocentric theorizations of time. ${ }^{12}$ On the other hand, bound up with phenomenal time are the questions which surface about time in the singular, thus about finitude, and about what gives meaning to life at the general, cosmological level. It is a matter of evaluation, guided by a history of reflection about what is liminally present in the significant events of our existence, yet transcends biography, concerning the apprehension of a sublime dimension to human existence, an experience of the ecstasy and epiphany of being. So, at one level, temporality encompasses the historical and cultural space of the emergence of the who of action and meaning, and at another level, it opens onto a critical hermeneutics and to a reflection which points to the apprehension that a self 'does not belong to the category of events and facts' (Ricoeur 1991, p. 193). We shall see how the implications for the formation of subjectivities and issues of refiguration and transfiguration link up with Ricoeur's approach in a way which avoids the collapse into species of psychologism, determinism and essentialism. Narrative, Ricoeur tells us, 'constructs the durable properties of a character' (1991, p. 195). It does so by emplotting the events of a life according to the rules of storytelling, relying upon the modalities of plot already existing in a culture. We make sense of our actions and the events in our lives by inventing fictions that figure them in the domain of the imagination. The sense of narrative identity that Ricoeur develops stresses the view that every identity is "mingled with that of others in such a way as to engender second-order stories which are themselves intersections between numerous stories. ... We are literally "entangled in stories" (Ricoeur 1996, p. 6).

In order to understand the mechanisms at work in subjective formation and change, we need to examine the three mimetic functions of narrative described by Ricoeur. Mimesis 1 refers to the prenarrative features that express basic human desire; it describes a 'semantics of desire' (Ricoeur 1988, p. 248); this formulation suggests perhaps the thetic function or phase of the signifying process as understood by Kristeva. I draw attention to Kristeva's (1974) analysis of significance because she makes a systematic connection between the process of identification and the process of signification by way of the functioning of the economy of desire, so that the complicity between sign and propositionality is underpinned by the relation between the semiotic and the semantic fields, in which the thetic functions as, at the same time, rupture and frontier, and thus as relay (Kristeva 1974, pp. 41, 42). My juxtaposition of Kristeva is meant to keep visible the psychic level of the process of figuration and refiguration, a level which is not so clear in Ricoeur, but which my discussion of Fanon brings to the fore. Mimesis 2 arises from the creative process of the configuration of experience, whilst Mimesis 3 refers to the narrative identity which results from repeated rectifications of Mimesis 2 in the course of reflection and

\footnotetext{
12 Temporality as lived is culturally and historically variable, as a good deal of ethnographic analyses have established. See also Fabian (1983) and Osborne (1995).
} 
rememoration. Thus, the third mimetic relation relates back to the first by way of a transformative praxis applied to the second (Ricoeur 1988, p. 248). Every narrative identity is a refigured identity, involving the action of a poiesis which accomplishes the weaving of the phenomenological and cosmological dimensions of being, working the fictional into the historical narrative to constitute a 'third-time' (1988, p. $245)$. The consequence is that the 'fragile offshoot from the union of history and fiction is the assignment to an individual or a community of a specific identity that we can call their narrative identity' (1988, p. 246). It is this identity which is refigured through the application of particular types of narratives existing in a culture which, through self-reflection, performs a hermeneutic and critical function. The constant refiguration of identity, or its possibility, brings up the question of the kind of narrative promoting such a process, so that narrative becomes the 'name of a problem' (1988, p. 249).

The point is that although '(l)ife is woven of stories told' (Ricoeur 1988, p. 246), these stories are not purely imaginary or fictional, for they make reference to a domain of reality that can be verified through attestation or testimony. On the one hand, the stories we tell about ourselves are segments of other people's stories about themselves and us, so that a self 'happens' at the point of intersection of many real lives. On the other hand, some of these narratives tell of events involving a whole community or period of time, that is, they inscribe a history, so that every self occurs 'at a point of intersection between fictive and historical narratives' (Ricoeur 1991, p. 186). Although history takes the form of a narration, it is important to avoid reducing history to a species of fiction, ${ }^{13}$ and thus abolish the question of truth, for instance regarding the Holocaust or colonial oppression. Ricoeur insists on maintaining the polarity between the two, using the notion of debt to make visible the responsibility which history owes to those who have been, namely, the responsibility to ensure that historical narrative does not fictionalize the dead, thus killing them twice over, but must 'return their "having-been" to them' (Ricoeur 1991, p. 186). The narrativity of identity does not abolish the 'reality' of the who, but shifts the question of the truth of subjectivity onto the ground of inter-subjectivity. The shared character of identity, the way in which we can think of ourself as a particular self only by reference to being-with-the-other, means that identity is always-already cultural. Indeed, self-reflection is the process whereby we apply to ourself historical and fictional narratives sedimented in our culture, so that 'self-constancy refers to a self instructed by the works of a culture that it has applied to itself' (Ricoeur 1988, p. 247). The example of becoming a parent that I noted earlier demonstrates how the process of figuration and refiguration brings into play the scripts and plots existing in a culture; they fill with content the vocabulary of selfhood that gives meaning to the events of a life and validates the sense of who we are. ${ }^{14}$

\footnotetext{
13 The discussion of history around the work of Hayden White is instructive in this context (see White 1978).

14 I would like to signal the element of refiguration which involves the anamnesis of what has been disavowed and buried in the course of previous figurations of subjectivity. The process of changing the subject is therefore a very complex one, working at the psychic level as well as at the cognitive, the ethical and the aesthetic levels.
} 
From what Ricoeur says, we could consider the refiguration of particular selves to occur, for example, as the result of 'working-through' in psycho-analytic practice or as the result of a process of rememoration when the biographical content of narrative identity encounters the historical refigurations and rectifications performed by historians. This is demonstrated in the way that feminist and 'Black' history have participated in the reconstruction of identity by giving people a different past and a different temporal framework for anticipating possible subjective projects. In the everyday, it is important to recognize that the most common narratives and narrations that function as models or scripts for 'identities' are now to be found in novels, films, plays, poetry, traditional tales, parables and so on, in which lives are emplotted and secrets of 'living well' are revealed or communicated in the form of lessons. The practice of everyday life is suffused with knowledges of all kinds, sometimes drawn from or authorized by theoretical accounts, for example, about the function of sexuality in the formation of the psyche, which become part of the stock of narratives people apply to themselves. In that sense, the three mimetic functions as described by Ricoeur should be read as shorthand for the complex process of the rectification of selves, a process irreducible to a simple linguistic event. The refiguration of identity depends on the conjunction of particular phenomena, involving action with others, and the retelling or re-emplotment of the biographical elements of a previous identity: it is a labour. It depends too on the quality and provenance of the narration, that is, its density, richness, depth, insight, emotional weight, voice, point of view or, more generally, everything that makes it an inexhaustible source for the hermeneutic task and that operates to disrupt normalizing closure. ${ }^{15}$

The process of subjective change has a diachronic dimension which Ricoeur indicates when he refers to the inscription of a notion of 'traditionality' located in the conceptual space bounded by the three-fold relation of mimesis. The term is used to try to account for the effectivity of history upon us, the way in which the past affects us independently of our will and the way we respond to the effect of history through an articulation of the past and the present. In that sense, traditionality can be understood as the term referring to the interweaving of two 'temporalizations of history' (Ricoeur 1988, p. 219) that cross each other, constituting particular identities at the points of intersection. A 'who' appears at that point of intersection where the history of a culture, sedimented and transmitted in its stock of knowledge, its narrations and 'texts', crosses the history of a named subject, constituting a particular consciousness. This is the mechanism by which we are so to speak sutured in history. Perhaps we could also try to imagine this process according to the analogy of the envelope, in the mathematical sense, rather than think of the crossing in terms of the point, since the latter tends to invoke a static moment rather than a continuous line or curvature. There is always the temptation to limit the indefinite character of the process of articulation, and thus the anxiety of uncertainty it provokes, by attempting a 'fusion of the horizons' (Ricoeur 1988, p. 221) of the space of experience and the horizon of expectation, forcing their coincidence or correspondence,

\footnotetext{
15 Grand narratives have functioned in this way, for instance in the guise of Marxism or feminist and colonial narratives of liberation.
} 
usually effected by ideological functioning of a totalizing doctrine or discourse or a metaphysics of transcendence.

Ricoeur's understanding of traditionality, besides, precludes the forgetting of the past, whether it is an active forgetting (as advocated by Nietzsche), or the result of repression or disavowal, or whether it is achieved by means of the obliteration of the past through a brutal break with it, for example, in ethnic cleansing and some forms of fundamentalism. The narrative of the present must remain open to the recognition of a heritage, or roots (Gilroy 1993a), with which one must come to terms. The problem concerns the way in which this dialogue with the past can be both dialogical and dynamic, that is, how the refigurations of the past and the present mutually condition each other whilst relating to the future as possibility and as difference, implying the effects of different 'routes' (Gilroy 1993a). Modernity as a period attests to the recognition of the tension between the two and the variability of the relationship between them. Any strategy which seeks to collapse the two is an attempt to refuse the possibility of a judgement of our presentness by reference to the difference between an imagined past and a projected future, and its legitimation in terms of some value like emancipation.

It is important to bear in mind that the issues of debt and of responsibility are implicated in this notion of a judgement of history, and, by the same token, the point of view of ethics in the temporalization of history. In other words, the way we narrate history \pm whether as difference, repetition, as logical necessity and so on \pm carries with it normative or prescriptive values since, in constructing the world in a particular way, every narration attempts to persuade or direct the reader or listener to act in a certain way. For example, an account of someone's action that relies on explanations in terms of genetic determination or essential tendencies \pm the debate about gender or ethnic differences is burdened by a surfeit of such claims \pm removes that action from the possibility of transformative practices, and thus from the openness to change on the basis of ethical considerations. But, as Ricoeur has pointed out, 'narrative already belongs to the ethical field in virtue of its claim \pm inseparable from its narration \pm to ethical justice' (Ricoeur 1988, p. 249).

\section{Some lessons for (dis)identification}

Let me pick out a number of themes as a way of summarizing the points that I want to signal in relation to the question of subjective transformation generally, and the question of postcolonial identity and its refiguration as a special case. At the level of the general protocols of analysis and critique, I would point out again the intersubjective and cultural dimension of identity, against notions of the autonomous singularity of the self and the conceptualization of a self-present 'I' acting as the originary point of agency. This heteronomous dimension is tied to the priority granted to temporality in the understanding of being and the implications for the theorization of identity and subjectivity, particularly the emphasis on the inter-connectedness or 'articulated unity' (Ricoeur 1988, p. 70) of the three ecstasies of time: the 
having-been, the making-present, the coming-towards. Central to connectedness is the functioning of the indirect discourse of narration as a way of giving reality to, or making phenomenal, the ontological standpoint. ${ }^{16}$ Narrative, as I said, mingles our individual history and our identity with that of others and their stories, so that I always multiply dispersed into a series of stories and acts involving others and their stories. This aspect of being-with is repeated in the connection of temporality and historicity through narration which I have examined by reference to the cultural and inter-subjective location and nature of the mechanisms for the (re-)formation of subjectivity. This location is far from being discursive alone, for we exist as embodied entities coupled to the material world. The standpoint of embodiment brings into focus the place of affect in these mechanisms. The sense of historicity that I have been developing considers both temporality and spatiality to be its constitutive dimensions, so that the world to which the subject is coupled is at once archive and monument, the space of a memorialization and of dwelling for being, and the space for an apprenticeship into ways of living that necessarily inscribe the ethical dimension.

It is important to highlight a number of problems relating to the effects of power for which we do not find clear indications in Ricoeur, in spite of the recognition of the agonistic terrain of the production of historical narratives. In particular, we need to address the question of the effects of power at two inter-related levels, the historical and the biographical. At the general level, there are the effects that operate in the making and telling of the particular history of communities and periods, so that every history is a particular temporalization, configured in the metanarratives which provide the broader canvas in relation to which individuals in any society locate their own minor or 'little' narratives. For instance, Fanon's counter-narratives of Africa, set against the occidentalist version and its narration of modernity, reveal the economic and racist interests that have shaped the latter version. At the other level, which refers to the domain of the experiential, we know that it is impossible to make sense of individual lives outside considerations of gender or race, class or caste and so on, and the power relations invested in them. So, in trying to transform subjectivities, one cannot avoid interrogating the power relations inscribed in everything that fills identities with content, namely, the cultural imaginary and memory constituted out of the authorizing great ideas, the beliefs, the myths, the sayings, the models and exemplars, the stories of deeds done, as well as everything that has been sedimented in the artistic output of a culture. It is for this reason that the remaking of postcolonial identities implicates the revision of the history of modernity. The politics of difference attached to feminist, postcolonial and other struggles provide ample evidence that this connection is inevitable. In keeping visible the 'big picture', I want to

\footnotetext{
16 Note Ricoeur's differences from Heidegger, for instance, in his critique of Being-towards- death. Furthermore, his understanding of historicality binds it to the notion of being-with and the 'they' or communitarian side of being-in-the-world (see Ricoeur 1988: 71ff.). Ricoeur has reservations about Heidegger's emphasis on the singularity, or aloneness, of the self, for example, in Heidegger's remark that we all die alone, and in his failure to prioritize being-with and the 'they'.
} 
signal that such a revision engages with a utopian anticipation of the future, that is to say, it calls up visions of alternative 'big pictures', thus alternative grand narratives.

To illustrate this, we can return to the text of Fanon, to the place where we find him describing how he feels entrapped in the narratives of colonial discourse about Europe's 'others' and constrained by the specific 'traditionality' in the narration of modernity. The past as told from the point of view of Europe and the colonizers is precisely what burdens him. It is a past that he cannot refigure whilst he remains within a particular 'mise-en-discours' and temporalization of history that appear to provide him with the instruments for the refiguration of identity, yet prove to be inadequate because the metanarratives of progress, rationality and emancipation, and liberty, that frame the conceptual and tropic space of this narration happen to be, at the same time, the shackles that bind him even more firmly the more he struggles with and against them. The force of these discursive shackles derives from the fact that they conceptually organize and encase the world and the imagination within the boundaries of narrativizations of experience that already inscribe the 'other' within an idea of 'otherness' that they have themselves specified. The embodied character of subjectivity intensifies the sense of being entrapped.

Something else is called for which Fanon finds in a different voice, interestingly in the poetic recovery of the memory of blackness and subjugation/subjectification, a memory denied in the discourse of the 'master', disavowed by the (liberal) cosmopolitan intellectual, yet lived as the trace of trauma, ready to erupt in violence. The injury of colonialism, multiply inscribed \pm in the body, in the psyche, in culture, in history and in the lifeworld \pm is refigured through the recognition of shared suffering transmuted in writing and 'art', and, just as centrally, through the transformative work of a critical hermeneutics. The argument here claims that there exists an artistic practice, mimetic or otherwise, ${ }^{17}$ that reveals the concealed or unpresentable features of experience and thought, working at the level of the intuitive and of the imaginary, bringing to presence a sublime and liminal dimension. The implication in both Ricoeur (1992) and Fanon (1970) is that without the work that art performs, that is, without poiesis, and the work of refiguration that it enables us to perform with respect to the 'who' of identity, life would be incoherent. From the point of view of resistance or counter-hegemony, the chemistry of disidentification works by alchemy, requiring a brew of a critical narration and incantations of an auratic power distilled in the alembic of poetic transfiguration. I will examine this in detail in Chapter 4, by reference to the idea of an ethics and an aesthetics of the self and in my discussion of the sublime. I will use Toni Morrison's Beloved as a case.

It is important, equally, to theorize the process of changing the subject by reference to ways of dealing with loss and trauma, that is, fully recognizing the centrality of affect for the process. Fanon's account of the sense of annihilation he experienced and the Negritude writings to which he turned in search of another speech express a

\footnotetext{
17 I use mimesis in the light of Taussig's analysis of 'active yielding' (1993, p. 46) to what is presented in certain kinds of representative or mimetic practices, indicating a functioning which reaches beyond mere repetition or mechanical imitation. Clearly, the domain of the aesthetic is implicated as soon as we speak of a mimetic function.
} 
multiplicity of losses: of identity and self-esteem, of history and rootedness, of face and agency. They pour into the abyss of an anterior and primary \pm that is, ontological \pm loss and lack, adding to the weight of anguish that pulls the abject 'other' into the cycles of psychic suffering. Fanon discussed the range of possible responses, such as self-hate, despondency, melancholia and violence. Clearly his own response, like that of Cesaire, for example, has been to invent ways of mourning and ways of overcoming these pains or ways of transmuting the memory of subjection into a transcendent dimension, drawing from the language of myth and the rhythms of another, fantasmatic and immemorial, way of being. At the end of Black Skin White Masks, Fanon invokes a utopian dimension \pm a relocated, non-Eurocentric humanism in this case \pm in his search for the legitimating principles of resistance and the basis of self-transformation. So hope and the promise of joy, along with historicity and responsibility, are also part of the equation.

The theme of an emancipation and of a liberation returns. It requires rephrasing in a new secular idiom. This new discourse of the desired future and of an acceptable present is inevitably inflected by the history of modernity, and the language that had developed with modernity to speak of emancipation and enlightenment. But it cannot be written except in the course of a rewriting of the history of modernity and the philosophical discourse which has nourished it, that is to say, in the course of a critical engagement with how the experience of modernity has been temporalized and monumentalized, and what it has signified. This is where the postcolonial (and feminist) question(ing) occupies a decisive place from the point of view of critique, for it is a questioning from the underside of modernity, its unspoken or hidden history, cast out as a poor relation, yet which carries within it the trace of the supplement that will undo the triumphalist narrative of emancipation. It opens up to a different reflection the 'hermeneutics of desire', the economy of sacrifice and the economy of the gift and their relation to the question of ethical responsibility and the temporality of being.

\section{References}

Appiah, Kwame Anthony. 1992. In My Father's House: Africa in the Philosophy of Culture. Oxford: Oxford University Press.

Benjamin, Walter. 1973. Illuminations. Trans. Harry Cohn. London: Fontana.

Bhabha, Homi. 1994. Location of Culture. London: Routledge.

Berman, Marshall. 1983. All That Is Solid Melts Into Air: The Experience of Modernity. London: Verso. Braidotti, Rosi. 1994. Nomadic Subjects: Embodiment and Sexual Difference in Contemporary Feminist Theory. New York: Columbia University Press.

Butler, Judith. 1990. Gender Trouble: Feminism and the Subversion of Identity. New York: Routledge. Butler, Judith. 1993. Bodies That Matter. New York: Routledge.

Butler, Judith. 1999. Revisiting bodies and pleasures. Theory, Culture \& Society 16 (2): 11-20.

Deleuze, Gilles and Guattari, Felix. 1985. Anti-Oedipus: Capitalism and Schizophrenia. Trans. H.R. Lane and Robert Hurley. Minneapolis: University of Minnesota Press.

Derrida, Jacques. 1995. The Gift of Death. Trans. David Wills. Chicago: University of Chicago Press.

Derrida, Jacques. 1997. Le Droit Á la philosophie du point de vue cosmopolitique. Paris: Editions Unesco.

Fanon, Frantz. 1970. Black Skin White Masks. Trans. Charles L. Markmann. London: Paladin. 
Grosz, Elizabeth. 1994. Volatile Bodies: Towards a Corporeal Feminism. Bloomington: Indiana University Press.

Henriques, Julian, Wendy Hollway, Cathy Urwin, Couze Venn, and Valerie Walkerdine. 1998. [1984]) Changing the Subject: Psychology, Subjectivity and Social Regulation. London: Routledge.

Irigaray, Luce. 1979. Et l'une ne bouge pas sans l'autre. Paris: Editions de Minuit.

Irigaray, Luce. 1984. Ethique de la difference sexuelle. Paris: Editions de Minuit.

Kristeva, Julia. 1974. La Revolution du langage poetique. Paris: Editions du Seuil.

Kristeva, Julia. 1983. Histoires d'amour. Paris: DenoeÈl.

Kant, Immanuel. 1992 [1784]. An Answer to the Question: What is Enlightenment? In Postmodernism: A Reader, ed. Patricia Waugh. London: Edward Arnold.

Lacan, Jacques. 1966. Ecrits, vol. 1. Paris: Editions du Seuil.

Levin, David Michael. 1985. The Body's Recollection of Being: Phenomenological Psychology and the Deconstruction of Nihilism. London: Routledge and Kegan Paul.

Lloyd, Genevieve. 1993. Being in Time. London: Routledge.

Lyotard, Jean-FrancËois. 1993. Un trait d'union. Sainte-Foy: Le Griffon D'argile.

Merleau-Ponty, Maurice. 1968. The Visible and the Invisible. Ed. Claude Lefort. Trans. Alfonso Lingis. Evanston, IL: Northwestern University Press.

Morrison, Toni. 1992. Playing in the Dark: Whiteness and the Literary Imagination. New York: Vintage Books.

Ricoeur, Paul. 1984. The Creativity of Language. In Dialogues with Contemporary Continental Thinkers, ed. Richard Kearney. Manchester: Manchester University Press.

Ricoeur, Paul. 1988. Time and Narrative, Vol. 3. Trans. Kathleen Blamey and David Pellauer. Chicago: University of Chicago Press.

Ricoeur, Paul. 1991. Discussion: Ricoeur on Narrative and Narrative Identity. In On Paul Ricoeur, ed. David Wood. London: Routledge.

Ricoeur, Paul. 1996. Reflections on a new ethos for Europe. In The Hermeneutics of Action, ed. Richard Kearney and Paul Ricoeur. London: Sage.

Rose, Nikolas. 1996. Identity, Genealogy, History. In Questions of Cultural Identity, ed. Stuart Hall and Paul du Gay. London: Sage.

Said, Edward. 1978. Orientalism. London: Routledge and Kegan Paul.

Young, Robert. 1990. White Mythologies: Writing History and the West. New York: Routledge.

Publisher's Note Springer Nature remains neutral with regard to jurisdictional claims in published maps and institutional affiliations.

Couze Venn was director of the Theory, Culture and Society Centre and latterly Professor of Cultural Studies at Goldsmiths, University of London until his death in 2019. 